\author{
S.J. Lee*, D. Pak \\ KIMEP University, Almaty, Kazakhstan \\ (Corresponding author's e-mail: diana.pak@kimep.kz)
}

\title{
Effects of sequence and storytelling methods on EFL development of an adult learner
}

\begin{abstract}
This article presents the effects of sequence and storytelling methods on an adult beginner learner's English language development. Being a powerful and natural way to learn, convey, and retain information, these methods offer a number of benefits, such as improving learners' language proficiency, increasing learner participation, providing learners with cultural experience and encouraging creativity. The following research questions guided the study: 1) How do sequence and storytelling methods motivate an adult language learner to improve English? 2) What linguistic aspects do sequence and storytelling methods develop in the learner's English? A qualitative research approach, specifically a case study, was used to investigate these questions. The findings demonstrate that sequence and storytelling methods of teaching EFL positively contribute to English speaking proficiency and empowerment by motivating the learner. The participant of this case study appreciated the benefits of sequence and storytelling teaching techniques as they addressed her individual needs and increased her learning enjoyment, cultural awareness, and language ability.
\end{abstract}

Keywords: EFL, sequence and storytelling methods, effects, an adult language learner, learner needs, motivation, empowerment, language proficiency.

\section{Introduction}

Sequence and storytelling methods offer a powerful and natural way to learn, convey, and retain information. Research in neuroscience [1] shows that the brain receives and retrieves human experience sequentially. Sequencing is the ability to comprehend an event's components in a given format, such as the beginning, middle, and end of a story or the steps that are followed in learning something in a given order. Sequencing in learning a foreign language calls for understanding the language from simple to complex and from general to specific terms. To understand the information provided, learners need to make sense of it as they read in order to remember it later. The ability to identify the beginning, middle, and end makes recalling important events manageable. It is essential to analyze how the sequence of events works in language learning. During language lessons that implement sequence and storytelling methods, blocked or interleaved study sequences can be used separately. Blocked and interleaved sequences differ in some aspects, such as the amount of repetition and alternation in different categories and the number of repetitions of the parts of progressively presented stimuli [2]. This means that foreign language learners are likely to learn, understand, and retrieve information when a sequential learning method is used [3].

In this study, we analyze the effects of sequence and storytelling methods on improving the English language of an adult beginner learner. We also examine the linguistic aspects of her learning. The following research questions guided this study: 1) How do sequence and storytelling methods motivate an adult language learner to improve English? 2) What linguistic aspects do sequence and storytelling methods develop in the learner's English?

\section{Literature Review}

Storytelling and sequence telling work interchangeably because a story has to follow a sequence from the beginning to the end in order to have a good flow. Using a sequence of events allows the learner to follow the occurrence of events without any confusion. This specific language teaching and learning method is also called TPRS (Teaching Proficiency through Reading and Storytelling). This TPRS method has several benefits, such as improving learners' language proficiency, increasing learner participation, providing learners with cultural experience and encouraging creativity.

Language Proficiency

Storytelling is one of the oldest forms of teaching, and it is still used in most societies as an informal method of teaching children in their homes. Stories are a powerful tool for teaching a foreign language as learners can naturally acquire the language in a meaningful environment. The language acquisition device 
(an innate ability to learn languages) is activated when exposed to a comprehensible input (language that can be understood) such as storytelling and sequence telling.

Borich [2] claims that storytelling activities and the sequencing method's application are significant in improving learners' speaking skills. Students who tell stories by themselves are independent as they are less likely to be distracted by others and have a better opportunity for practice. The learners express a positive attitude and perceptions towards the storytelling method as it is less strict and more fun. Through storytelling, learners can recall new vocabulary more efficiently, practice speaking skills frequently, improve their learning performance, and become competent English language speakers.

Storytelling emphasizes the student's role in constructing knowledge, relying on the student's prior experience instead of the instructor's skill to transmit knowledge. It has a better outcome when used hand in hand with the Total Physical Response approach, in which learners acquire a second language by making sense out of actions or movements. It is a highly personalized, comprehensive, and contextualized approach that does not impose stress or anxiety on the learners. This makes learning exciting and more manageable. The learning environment created by the Total Physical Response approach is also conducive to learning a foreign language [4].

The vast majority of the studies currently available conclude that the TPRS approach has many advantages over traditional teaching methods. In their meta-analysis of 13 studies, Lichtman and Krashen [5] found that speaking skills are mastered fastest through storytelling, followed by writing, vocabulary, and grammar competence. In addition, stories are an excellent tool for introducing, practicing, revising, and improving pronunciation skills [6]. Kalantari and Hashemian [7] discovered that a foreign language vocabulary develops significantly through storytelling.

The TPRS approach has three stages. In the first two stages, learners develop receptive skills. There are several benefits of TPRS for both the learner and the teacher. First, it makes learning a foreign language less complicated. Storytelling helps learners understand new words more easily and exposes them to the way sentences are constructed in the foreign language. It also helps learners understand how to create a connection between words and flow.

Participation and Enjoyment

Good stories capture the attention and interest of listeners. Wood [7; 18] conducted in-class action research to determine whether storytelling offers any advantages to primary school students' motivation and participation when learning a foreign language. He reported that «the children enjoyed taking part in the activities even if their level of English was very limited, the idea that they wanted to learn and were not afraid to make a mistake was very pleasant to see». In other words, pupils would overcome their insecurities in a foreign language when they were involved in a storytelling process and learning was enjoyable for them. The results of Wood's [7] study were confirmed by Martinez [6] and Gonzalez [8], who investigated the impact of storytelling on primary school children's interest in learning English.

\section{Cultural Awareness}

Along with the beneficial language learning outcomes of storytelling, students can develop a sense of cultural and emotional diversity. Martinez [6] highlights the importance of using literature, such as authentic picture or story books, to develop learners' cultural competence in a target language. Through becoming familiar with cultural and social contexts different from their own, they start thinking critically about the world and their place in it:

Stories are windows open to the world. They bring in views about different people, new countries and diverse cultural values, can prepare learners for openness, awareness, tolerance, and acceptance towards other ways of understanding life and stories about different cultures can help integrate children from different migrant backgrounds [Ioannou-Georgiou \& Verdugo, 2011 as cited in 7; 4].

\section{Creativity in Learners and Teachers}

Gonzalez [8] asserted that telling stories motivates learners to use a foreign language more creatively than what is required by standardized textbook tasks because stories are interesting, engaging, and imaginative. Storytelling gives more freedom to use spontaneously received knowledge. After introducing the storytelling approach as a supplement to the primary curriculum of a Spanish class with elementary school pupils and adults, an experienced second language teacher, consultant, and curriculum developer reflected:

Now, more than ever, I recognize the importance of working hard to be the creative, effective teacher my students deserve. And I know from their positive feedback that storytelling is making a difference in how they think about the experience of learning a foreign language [2]. 
Overall, it is clear that in addition to its well-known benefits, such as amusement and socialization, storytelling can bring a lot of learning benefits as a part of the TPRS approach. This fact explains the tremendous popularity of the TPRS approach.

\section{Methods and Materials}

This research aims to analyze the effects of sequence and storytelling methods on the English language reading and speaking skills of an adult beginning learner. For the method of current study, we chose a qualitative research because it is characterized as well-defined explanations and interpretations of what a researcher hears or observes by means of field notes, interviews, conversations, recordings and other relevant data [9]. Specifically, this qualitative research is a case study that involves investigating a bounded case for a designated length of time, with the resulting data collected through different methods such as interviews, documents, and reading materials. Using Creswell and Poth's [9] principles, we selected one case of EFL learning methods as storytelling and sequence telling and decided to examine a case within a single context of an adult beginning learner. In particular, we offer a case study of a Korean female's English language learning by examining descriptive data such as the findings from in-depth interviews and the participant's learning progress.

\section{Participant}

The participant of this case study is Kim, an English language learner. Kim is a Korean native and speaks English as a foreign language; she majored in Korean dance and learned little English language in the past. The participant relocated to Almaty, Kazakhstan, because of her husband's profession. Kim has one daughter and one son who both attend an international school. Although Kim was an absolute beginner of the English language, she was highly motivated to learn English to support her children's education and communicate with their teachers.

Data Collection and Procedures

For this case study, one of the researchers examined her progress and recorded her language development. Data were collected through semi-structured interviews and teaching and learning reports over the course of 5 months of English lessons. The interviews began with the main questions, which were written ahead of time; follow-up questions were spontaneously formed depending on how the participant answered or reacted. The interviews took place in the office of one of the researchers. Two formal interviews were conducted, and the length of each was about 1 hour and 20 minutes. English lessons also took place at the researcher's office twice a week from October 2019 to February 2020.

During the first ten weeks of the lessons, ten different daily life episodes were overviewed and practiced, including: 1) how to make a bowl of cereal; 2) how to toast bread; 3) how to fry eggs; 4) how to cook ramen; 5) how to wash your hands; 6) how to clean the table; 7) how to wash the dishes; 8) how to do laundry; 9) how to take care of your dog; and 10) how to use an ATM. The topics are excerpted from English for Everyday Activities [10], and each episode consists of 8 basic sentences. One topic was covered for each week, and the researcher recorded all the sequences in English. The participant practiced reading the sequence every day at least three times and sent her voice recordings of the assigned sequence every day to the researcher as an assignment. During the last eight weeks, the researcher read an English book series called Little People, Big Dreams [11] to Kim. In addition, the researcher recorded her reading-aloud of the book and sent the audio file to Kim. Then, Kim listened to the story, read-aloud, recorded her storytelling, and sent her recording back to the researcher as a daily assignment.

\section{Data Analysis}

Interviews were conducted in Korean, primarily because the participant was more comfortable using her first language when expressing her ideas and requested Korean language in the interview procedure. The data were then transcribed in Korean. The necessary data were extracted from the original Korean transcripts, and then all relevant parts of the interviews were translated into English. Finally, the acquired information to reveal Kim's language development was thoroughly analyzed from in-person lessons and audio recordings. These were used to answer the research questions for this paper.

\section{Results and Discussion}

This section aims to present the qualitative data analysis results. It starts with the description of the participant's background and discusses the effects the sequence and storytelling methods had on the participant's language skills. 
Lack of Motivation in the Past

«No, I haven't [learnt English]. Even when I had to, I didn't. I wasn't interested».

External factors had no positive influence on the participant's motivation to learn English in the past. Starting from grade 7 at a secondary school in South Korea, the participant was engaged in English language classes that did not help her learn English. This happened for two reasons: first, she prioritized and dedicated her time to dancing; second, English was not as popular then as it is now, so she was not motivated to learn or do well in the class. In high school, in addition to the college preparatory curriculum, the participant enrolled in a private English Academy because her friend asked Kim to join. However, Kim felt very stressed and frustrated as the English classes were conducted by English native speakers. The participant did not pursue learning English during college either. Later, her parents suggested her to go abroad to study English, but her plans changed. Regardless of the variety of opportunities to master English, the participant lacked motivation and failed in learning.

Improved Motivation

Once the participant felt internally driven and had greater motivation, she started making progress:

«If I learnt English a bit, then I'd be able to recognize things that I didn't know before, and I want to travel abroad by myself, speaking English».

«... he [husband] tells me stuff, but as it gets repeated, and as he has his own things to do and he tells me to do things on my own, I feel frustrated. So I thought, if only I could speak English, then I could've taken care of my kids' school matters at their international school».

When she moved with her family to Almaty, Kazakhstan, Kim suddenly found herself in an international environment. Her children went to an international school where English was used as a medium of instruction. Her husband, a fluent English speaker, was not always nearby to translate things for her, and being recognized as a foreigner, she would be offered menus/service in English. She could not express herself in a foreign country, and she lost her voice because of language barriers:

«As I came here [Almaty] I felt many things».

«There were many mothers who spoke English well».

«... they [foreign mothers living in Almaty] were sending their kids to international schools where kids spoke English. I envied them because they spoke to the teachers. When I went to the school, I always had to bring my husband».

«I want to learn [English] and it's the first time I come to a place with so many foreigners».

This is how the participant developed intrinsic integrative motivation (a drive to do something that stems from internal rewards to become a member of a target language speaking community), which strengthened her stamina and persistence in the foreign language learning journey.

Transferring Extrinsic to Intrinsic Motivation

The continued use of the sequence and storytelling methods help the learner to become interested in the English language. Kim says,

«I can't say that I'm confident yet, but I feel that I want to do it».

In the same line, these methods of learning gave the participant greater intrinsic motivation (a drive to do something that stems from internal rewards) to learn the language:

«And I feel a sense of achievement, as I'm learning something new before I sleep. Something I haven't done before».

Many people find it embarrassing to speak English when they are not competent yet. This is because they do not have enough knowledge and confidence to speak in front of others; however, as they keep hearing and practicing good English from others, they get more confidence and start speaking it themselves. The recordings and discussions with learners help to build their oral skills. Kim says,

«Therefore, I should be able to speak English well enough to communicate. And the feeling that I can communicate with other people empowers me, because language allows people to communicate».

She noted her daily improvements and attributed them to the zeal she has developed in the process of learning. She is confident that with time her speaking skills will be perfect, and she will be able to communicate in English with other people. This is why she keeps recording (practicing English) even late at night.

Empowering Introverted Learners

Sequence and storytelling methods help empower learners through small achievements (recordings), self-actualization, and psychological comfort. Once a learner has experienced the positive side of these learning methods, they can gain courage and comfort in learning the language without fear of failing to understand. 
The data yielded by this study provide convincing evidence that one of the positive effects of the sequence and storytelling methods is learner empowerment. The participant highlighted that her emotional and psychological state during the study was comfortable and secure:

«I can't say that I'm confident yet, but I feel that I want to do it».

«I really want to study now, even if I'm awful. [I want to do it] Every day, without skipping».

«Therefore, I should be able to speak English well enough to communicate. And the feeling that I can communicate with other people empowers me, because language allows people to communicate».

It seems fair to suggest that breaking a story into meaningful and manageable chunks takes away the cognitive load of processing a complex assignment and reduces anxiety:

«I felt that I could do it [read in English]».

On top of that, every small achievement (i.e., recording) gave her a sense of accomplishment and boosted her confidence in learning.

«As I'm continuing to do this, I'm getting more determined. Even when I read it roughly, I feel grateful to myself as I've done something that day. If I don't do it, I feel uncomfortable before I sleep».

"When I look at it and I can see I've done a lot. And I think to myself that I maybe can be better at it, if I try».

«And I feel a sense of achievement, as I'm learning something new before I sleep. Something I haven't done before».

«Sending emails every day is also encouraging me, the feeling that I should send it (the recording) to you».

«When I feel tired, I could feel like skipping it and do it tomorrow instead, but the fact that I have to send the email to you has helped me a lot».

Sending a recording before going to bed became a new addition to her boring routine in a foreign country. This studying routine really empowered her because Kim gained confidence out of these small achievements:

«Something I can do every day...»

«... studying a language and making a routine out of it».

English Language Proficiency

The participant was eventually able to capture concepts systematically through this sequential method of learning. Since Kim could not read in English, oral instructions were a large part of learning; hence sequence and storytelling methods were very effective. For instance, it was easy for Kim, a beginner, to grasp the meaning of simple English words as they were gradually presented in order from the simplest to the most complex words. Storytelling and speaking combined with the sequential method helped her perfect her pronunciation of words and reading as well. It also helped her to gradually gain the ability to construct short sentences logically and comprehensively. In this way, she could learn more vocabulary as her interest in reading in English grew.

Thus, the observational data from this study suggest that sequence telling helps the foreign language learner understand how words are arranged in the new language as well as the sentence and phrase structure. It is one way of helping learners master their use of the new language. Specifically, sequence telling helps them understand the beginning, middle, and end of a story and ensures that they can create a plot while creating their own story. It also helps eliminate misunderstandings that are likely to occur when the learner does not understand how words are arranged in a language.

Furthermore, storytelling motivated the participant to continue learning by internalizing ideas more quickly through the plot. This finding suggests that narrating incidents in the story helps learners remember the specific vocabulary that they came across in their reading; they can also relate to what is going on in the story and imagine it in real life. This also boosts their ability to vividly remember specific terms and their respective meanings. Storytelling motivates them to do more beyond their readings. They are therefore inspired to learn on their own, fostering their understanding of the language. They grow to love English language sounds, pronunciation, and contents of sequence-telling and many other significant components.

The art of storytelling also creates a sense of connection for a language learner. Kim developed more interest in learning English when she continuously progressed through story recording and sharing the recordings with her tutor. Every time she felt like she made a slight improvement, she was more inspired to keep doing the same every day to improve her English. Storytelling connects the learner to what is happening at that moment, fostering open-mindedness and the ability to capture a new idea. 


\section{Conclusions}

Using the sequence and storytelling methods of learning is one of the most effective language-learning techniques. They involve training learners by exposing them to the simplest concepts of language and moving gradually to the most complex while ensuring that they understand every step. Storytelling involves the extensive reading of stories in the language, then sequencing them by telling the story captured in the reading. These learning methods increase learners' motivation to learn and become more proficient in the language. The more motivated the learners are, the more they are willing to explore on their own, which helps acquire their English skills. It is also evident that using sequential and storytelling methods of language learning helps to transfer extrinsic motivation into intrinsic inspiration. The more the listener gets excited about what they are engaging with, the more they are motivated to read more on the subject.

Storytelling also creates a sense of connection to real-life events. The use of stories builds trust and familiarity, allowing the learners to engage with the story where they are and making them open to more ideas, hence, more receptive to the basics of the language. It also helps the reader make connections between the story and reality. Considering all these benefits of the sequence and storytelling methods, we suggest that language teachers and material developers implement this technique for effective teaching and creative language learning activities.

\section{References}

1 Fletcher, P.C., Zafiris, O., Frith, C.D., Honey, R.A.E., Corlett, P.R., Zilles, K.,\& Fink, G.R. On the benefits of not trying: brain activity and connectivity reflecting the interactions of explicit and Implicit sequence learning. Cerebral Cortex, 2004, 15(7), $1002-1015$.

2 Borich, J. Teaching a foreign language through storytelling. Education Week website, 2012, April. Retrieved from https://www.edweek.org/tm/articles/2012/04/02/tln_borich.html.

3 Slavic, B. TPRS and comprehensible input training, 2016.

4 Kalantari, F. \& Hashemian, M.. A storytelling approach to teaching English to young EFL Iranian learners. English Language Teaching,2015. 9, 221. 10.5539/elt.v9n1p221.

5 Lichtman, K., \& Krashen, S. Show me the data: Research on TPRS. NTPRS 2013 (National TPR Storytelling Conference), Dallas, TX., 2013, July.

6 Martinez, I. B. A story-based approach to teaching English. Encuentro 17, 2007, 52-56 б.

7 Wood, J.D. Using stories to help children learn a foreign language. University of Granada (Doctoral dissertation), 2016.

8 Gonzalez, L. I.P. Teaching English through stories: A meaningful and fun way for children to learn the language. SciELO, 12(1), 2010 p. $95-106$.

9 Creswell, J.W. \& Poth, C.N. Qualitative research and inquiry design: choosing among five approaches. Sage, 2018.

10 Zwier, L.J. English for everyday activities: A picture process dictionary: Multi-skills activity book. Compass Publishing, 2011.

11 Shelley, M. Little People, Big Dreams. Frances Lincoln Publisher, 2019.

$$
\text { С.Д. Ли, Д. Пак }
$$

\section{Ересек оқушының ағылшын тілін шет тілі ретінде дамытуына тізбектік және баяндау әдістерінің әсері}

\begin{abstract}
Мақалада жаңадан бастаған ересек оқушының ағылшын тілін дамытуына тізбектік және баяндау әдістерінің тигізген әсері сипатталған. Ақпаратты алудың, берудің және сақтаудың қуатты және табиғи тәсілі ретінде бұл әдістер студенттердің тілдік дағдыларын жақсарту, сабаққа деген қызығушылығын арттыру, мәдени тәжірибе және шығармашылық сияқты бірқатар артықшылықтарды ұсынады. Зерттеу мына сұрақтарға негізделген: 1) Тізбектік және баяндау әдістері ересек оқушыны ағылшын тілін жетілдіруге қалай ынталандырады? 2) Тізбектік және баяндау әдістерін қолдана отырып, қандай лингвистикалық аспектілерді дамытуға болады? Осы мәселелерді зерттеу үшін сапалы зерттеу әдісі, атап айтқанда, тақырыптық зерттеу қолданылған. Зерттеу нәтижесінде ағылшын тілін оқытуда тізбектік және баяндау әдістерін қолдану ағылшын тілінде сөйлеуге оң ықпалын тигізгендігін және олардың мүмкіндігін кеңейте отырып, ынталандыратынын көрсетті. Қатысушылар бұл әдістердің артықшылықтарын бағалады, өйткені аталған әдістер олардың жеке қажеттіліктерін қанағаттандырды және оқуға деген қызығушылығын арттырып, мәдени танымы мен тілдік дағдыларын кеңейтті.
\end{abstract}


Кілт сөздер: ағылшын тілі шет тілі ретінде, тізбектік және баяндау әдістері, ықпал, ересек тіл үйренуші, тіл үйренуші қажеттілігі, ынтасы, мүмкіндіктерді кеңейту, тілді меңгеру.

\author{
С.Д. Ли, Д. Пак
}

\title{
Влияние методов последовательности и повествования на развитие английского как иностранного языка у взрослого учащегося
}

В статье описано влияние методов последовательности и повествования на развитие английского языка у взрослого начинающего учащегося. Будучи мощным и естественным способом обучения, передачи и сохранения информации, эти методы предлагают ряд преимуществ, такие как улучшение языковых навыков учащихся, увеличение вовлеченности, культурного опыта и творческого потенциала. Авторы статьи в ходе исследования пытались найти ответы на следующие вопросы: 1) Как методы последовательности и повествования мотивируют взрослого студента улучшить свой английский? 2) Какие лингвистические аспекты могут быть развиты при использовании методов последовательности и повествования? С этой целью ими был применен качественный исследовательский подход, в частности, тематическое исследование. Полученные результаты позволили авторами заключить, что данные методы положительно влияют на владение английским языком и расширяют возможности учащегося, мотивируя его.

Ключевые слова: английский как иностранный язык, методы последовательности и повествования, влияние, взрослый студент, потребности учащегося, мотивация, расширение возможностей, владение языком. 